\title{
Мультидисциплінарний супровід вагітних і породілей із вродженою вадою серця
}

\author{
Сіромаха С. О. ${ }^{1}$, Давидова Ю. В., ${ }^{1,2}$, Лиманська А. Ю. ${ }^{2}$, Лазоришинець В. В. ${ }^{1}$ \\ ${ }^{1}$ ДУ «Національний інститут серцево-судинної хірургії імені М. М. Амосова НАМН України» (Київ) \\ ${ }^{2}$ ДУ «Інститут педіатрії, акушерства та гінекології імені академіка О. М. Лук'янової НАМН України» (Київ)
}

\begin{abstract}
GUCH-пацієнти - окрема когорта пацієнтів, які зазвичай мають певний ступінь серцевої недостатності, підвищений ризик розвитку інфекційного ендокардиту і синдрому раптової серцевої смерті та потребують додаткових втручань на серці. Експерти Європейського товариства кардіологів (ESC) розглядають стосовно них також питання медичного супроводу вагітності, пологів і післяпологового періоду. В Україні з 2013 року функціонує мультидисциплінарна команда з фахівців НІССХ імені М. М. Амосова та Інституту ПАГ НАМН України. Консультативну допомогу за цей час надано 2815 вагітним, 116 проліковано в стаціонарі. До групи GUCH-пацієнток увійшли 64 жінки, з яких 61 - вагітна, 3 - породіллі. У 53 прооперованих жінок загалом було проведено 42 втручання на серці та судинах, 18 кесарських розтинів. Серед операцій на серці та судинах були «закриті» та ендоваскулярні втручання $(n=23)$, операції зі штучним кровообігом $(\mathrm{n}=19)$. У плановому порядку проведено 23 кардіохірургічні операції, в екстреному та невідкладному - 19. Одна материнська і дві фетальні втрати спостерігалися в групі вагітних (породілей), що підлягали екстреним втручанням зі штучним кровообігом. Більше ні материнських втрат, ні фетальних втрат не було. В усіх інших прооперованих жінок $(n=47)$ вагітність закінчилася без ускладнень. Сучасний рівень надання спеціалізованої допомоги GUCH-вагітним значно знижує ризик смертності та інвалідизації матері та дитини. Першою лінією захисту GUCH-жінки фертильного віку є первинна профілактика великих кардіальних подій - іiі предгравідарна підготовка до вагітності, мультидисциплінарний супровід такої жінки протягом усієї вагітності, пологів і післяпологового періоду.
\end{abstract}

Ключові слова: вагітність, дорослі з вродженою вадою серия, мультидисциплінарна допомога.

Вроджена вада серця (ВВС) - аномалія структури і функції серця та/або магістральних судин, яка існує при народженні дитини. Вроджені вади серця формуються внаслідок порушення ембріогенезу в період 3 2-го по 8-ий тиждень гестації з моменту виникнення ангіогенетичного скупчення клітин на місці зачатка серця (18+1 день гестації) до завершення формування стулок аортального клапана та синусів Вальсальви (приблизно 55 день гестації) [1]. Частота народження пацієнтів із ВВС становить 7-9 випадків на 1000 народжених живими [2].

На сьогодні, відповідно до запропонованої світовим кардіохірургічним товариством класифікації, існує більш ніж 160 нозологічних одиниць ВВС і понад 210 видів оперативних втручань при них [3].

У нинішню, кардіохірургічну еру в середньому $85 \%$ малюків із ВВС досягають дорослого віку, частка пацієнтів із прооперованим у дитинстві серцем або неоперованою ВВС становить 2800 осіб на 1 млн населення [4]. Відповідно до літературних даних, загальна виживаність пацієнтів після корекції ВВС до 40 років сягає $95 \%$, до 50 років - 92\%, до 60 років $88 \%$ [5].

Саме дорослі з оперованим у дитинстві серцем або 3 неоперованою ВВС і формують окрему когорту паці- єнтів - GUCH-пацієнти (GUCH - grown-up with congenital heart).

Якість життя пацієнтів після перенесеної в дитинстві операції на серці є питанням контроверсивним. 3 одного боку, відповідно до літературних джерел [6], такі діти мають більшу схильність до відставання в навчанні, частіше пропускають школу, частіше мають алергічні прояви та неврологічне відставання. А ось у дорослому віці пацієнти після операції на серці з приводу ВВС демонструють досить активну соціальну позицію в суспільстві. Як доводить дослідження E.H.M. van Rijen [7], більшість таких пацієнтів створюють сім'ї, майже в кожного третього є діти. I для багатьох із них мати проопероване серце - це додаткова мотивація до більш активного способу життя, в тому числі й у питанні реалізації функції материнства.

GUCH-пацієнти, як правило, мають певний ступінь серцевої недостатності, що зумовлено низкою факторів - таких, як резидуальні дефекти перегородок, легенева гіпертензія, нескориговані компоненти BBC, а також паліативні втручання. Аритмії є основною причиною госпіталізації дорослих пацієнтів із ВВС. Синдром раптової серцевої смерті - ще одне характерне ускладнення віддаленого періоду в цієї когорти пацієнтів [8]. GUCH-пацієнти мають підвище- 
ний ризик розвитку інфекційного ендокардиту, деякі $з$ них потребують трансплантації серця (серця-легень), імплантації механічних пристроїв підтримки роботи серця, оперативних та інтервенційних втручань із приводу залишкових компонентів ВВС. Окремо експерти Європейського товариства кардіологів розглядають питання медичного супроводу вагітності, пологів і післяпологового періоду в жінок із GUCH-когорти [9].

Відповідно до даних світової літератури [10], виношування вагітності (більше 20 тижнів гестації) у жінок iз ВВС не перевищує 90\% при простих ВВС і 48-50\% при складних. Особливо несприятливим є прогноз вагітності при таких ВВС: аномалія Ебштейна, коригована транспозиція магістральних судин (ТМС), тетрада Фалло, частковий атріовентрикулярний септальний дефект, ціанотичні ВВС, гемодинамічно скориговані BВC (кровообіг Фонтена). Крім того, у таких жінок існує значний ризик розвитку гіпотрофії плода, ембріота фетопатій [11].

В Україні на сьогодні проживає значна кількість жінок фертильного віку з оперованим серцем або «малими» формами ВВС, а також жінок, прооперованих паліативно, або тих, що свого часу підлягали гемодинамічній корекції складної ВВС. 3 них приблизно 700-1000 на рік вступають у фертильний вік, причому щороку ця кількість збільшується на 200-300 осіб. За розрахунками, в Україні на сьогодні проживають до 12000 жінок з оперованим у дитинстві серцем. Всі ці жінки потребують обов'язкового преконцепційного консультування та предгравідарної підготовки. Лише такий сучасний підхід і мультидисциплінарний супровід вагітної з кардіальною патологією мінімізує ризики як для матері, так і для дитини.

В Україні, відповідно до рекомендацій Европейського товариства кардіологів [10], з 2013 року функціонує мультидисциплінарна команда, до якої входять фахівці двох академічних закладів - ДУ «Національний інститут серцево-судинної хірургії імені М. М. Амосова НАМН України» (НІССХ імені М. М. Амосова) та ДУ «Інститут педіатрії, акушерства та гінекології імені

\section{Таблиця 1}

Група GUCH-вагітних (породілей) з обструкцією лівих відділів серия

Патологія Кількість

Коарктація аорти 7

Вроджений аортальний стеноз, що, як правило, супроводжувався постстенотичною аневризмою аорти

Субаортальний стеноз

ГКМП, обструктивна форма

Усього

19 32

* ГКМП - гіпертрофічна кардіоміопатія

академіка О. М. Лук’янової НАМН України» (Інститут ПАГ).

Метою нашої співпраці є зниження рівня материнської та малюкової смертності та інвалідизації вагітних жінок (породілей) і новонароджених.

Матеріали і методи. Спеціалізованої мультидисциплінарної допомоги в період із грудня 2013 року по лютий 2019 року потребували 2815 вагітних, направлених до консультативної поліклініки НІССХ імені М. М. Амосова. Після проведення експертного кардіоскринінгу та стратифікації кардіоваскулярного материнського ризику ми виокремлювали групу вагітних 3 «особливими» потребами, яку протягом усієї подальшої вагітності, пологів і післяпологового періоду спостерігали спільно з фахівцями Інституту ПАГ. За наявності високого кардіоваскулярного ризику пацієнток госпіталізували до НІССХ імені М. М. Амосова 3 метою проведення медикаментозної терапії, кардіохірургічного втручання або розродження. Протягом зазначеного періоду госпіталізації потребували 116 жінок.

Групу GUCH-пацієнток становили 64 жінки, з яких 61 - вагітна, 3 - породіллі. Зі структурними ВВС спостерігалися 52 пацієнтки, із вродженими аномаліями провідної системи серця - 12 жінок. Аномалії розвитку провідної системи серця були представлені вродженою атріовентрикулярною блокадою $(n=9)$, перебіг якої ускладнився під час вагітності, та суправентрикулярними тахікардіями за типом WPW-синдрому $(n=3)$. У підгрупі вагітних із вродженими порушеннями ритму серця було проведено 11 втручань - 7 імплантацій штучного водія ритму серця (ШВРС), 1 постановка тимчасового ШВРС та 3 радіочастотні абляції вогнищ аритмій.

Спектр структурних уроджених патологій серця i магістральних судин був досить широким: він представлений 15 різними видами ВВС. Для зручності презентації ми їх розподілили на такі групи: група вад, що супроводжуються стенозом лівих відділів серця (табл. 1), «ціанотичні» ВВС (табл. 2), ВВС із підсиленим легеневим кровотоком і високою гіпертензією в легеневій артерії (табл. 3).

Крім того, до когорти GUCH-вагітних увійшли дві пацієнтки із синдромом Марфана та аортопатією.

Серед госпіталізованих у клініку НICCX імені М. М. Амосова вагітних (породілей) були пацієнтки 3 радикально оперованою ВВС і задовільним результатом корекції $(\mathrm{n}=4)$, з ВВС, оперованою паліативно або зі значними резидуальними компонентами вади $(n=13)$, та GUCH-вагітні з неоперованою BBC $(n=35)$. У підгрупі вагітних після радикальної корекції ВВС із задовільним ii результатом були пацієнтки 3 такими втручаннями: стан після корекції субаортального стенозу, коарктації аорти, операції Росса-Кона та імплантації ШВРС (n=1), стан після операції артеріального переключення при ТМС $(n=1)$, стан після радикальної 


\section{Таблиця 2}

Група GUCH-вагітних (породілей) із «ціанотичними» BBC

\begin{tabular}{lc} 
Патологія & Кількість \\
\hline Тетрада Фалло & 3 \\
\hline Стеноз легеневої артерії & 3 \\
\hline ПВМС від ПШ & 1 \\
\hline ТМС & 1 \\
\hline КТМС & 1 \\
\hline Єдиний шлуночок (АТК, АЛА) & 3 \\
\hline Аномалія Ебштейна & 1 \\
\hline Усього & 13
\end{tabular}

* ПВМС - подвійне відходження магістральних судин від правого шлуночка, ТМС - транспозиція магістральних судин, КТМС - коригована ТМС, АТК - атрезія тристулкового клапана, АЛА - атрезія легеневої артерії

корекції повної форми атріовентрикулярного септального дефекту $(\mathrm{n}=1)$, стан після радикальної корекції аномалії Тауссіг-Бінга (n=1). Підгрупа вагітних із ВBC, прооперованих паліативно або з незадовільним результатом, складалася з пацієнток із такими діагнозами: стан після корекції субаортального стенозу, наявність ВАП з ВГЛА (n=1), стан після протезування мітрального клапана з приводу вродженої мітральної недостатності, тромбоз протеза $(\mathrm{n}=1)$, стан після пластики мітрального клапана з приводу його вродженої недостатності, виражена мітральна недостатність $(\mathrm{n}=1)$, коригована ТМС, стан після звужування легеневої артерії (ЛА) $(\mathrm{n}=1)$, атрезія тристулкового клапана, стан після накладання анастомозу Глена $(\mathrm{n}=1)$, атрезія легеневої артерії II типу, АТК, стан після операції Фонтена $(\mathrm{n}=1)$, єдиний шлуночок серця, стан після звужування ЛА, усунення коарктації аорти $(\mathrm{n}=1)$, стан після усунення субаортального стенозу, рецидив $(\mathrm{n}=1)$, комбінована аортальна вада з перевагою стенозу, стан після аортальної вальвулотомії $(\mathrm{n}=1)$, стан після усунення коарктації аорти, рецидив $(\mathrm{n}=1)$, ГКМП, стан після операції Морроу, рецидив ( $\mathrm{n}=1)$, стан після протезування аортального клапана, рестеноз за рахунок утворення панусу $(\mathrm{n}=1)$, стан після радикальної корекції подвійного відходження магістральних судин від правого шлуночка, трифасцикулярна атріовентрикулярна блокада $(\mathrm{n}=1)$.

У пацієнток із неоперованою ВВС зустрічалися такі діагнози: вроджений стеноз аортального клапана 3 аортопатією $(\mathrm{n}=16)$, коарктація аорти $(\mathrm{n}=6)$, стеноз легеневої артерії $(\mathrm{n}=3)$, тетрада Фалло $(\mathrm{n}=2)$, субаортальний стеноз $(\mathrm{n}=2)$, ГКМП, обструктивна форма $(\mathrm{n}=2)$, аневризма аорти при синдромі Марфана $(\mathrm{n}=2)$, аномалія Ебштейна $(\mathrm{n}=1)$, ВАП із ВГЛА $(\mathrm{n}=1)$.

Стратифікацію кардіоваскулярного ризику ми проводили за трьома шкалами: модифікованою шкалою

\section{Таблиця 3}

Група GUCH-вагітних (породілей) із підсиленим легеневим кровотоком і ВГЛА

\begin{tabular}{lc} 
Патологія & Кількість \\
\hline Відкрита артеріальна протока & 2 \\
\hline Вроджена недостатність МК & 2 \\
\hline Атріовентрикулярний септальний дефект & 1 \\
\hline Усього & 5 \\
* МК - мітральний клапан &
\end{tabular}

BOO3 (mWHO) та шкалами ZAHARA i CarPreg. За шкалою ZAHARA вагітні набрали від 0,75 бала $(7,5 \%$ вірогідності кардіальних ускладнень) до 6,75 бала (70\% вірогідності кардіальних ускладнень), у середньому 3,0 бали. За шкалою CarPreg пацієнтки набрали від 0 до 2 балів (ризик кардіоваскулярних ускладнень - 75\%), у середньому 1,5 бала. За модифікованою шкалою ВОО3 розподіл відображено на діаграмі 1.

Після проведення обстеження та мультидисциплінарного консиліуму фахівців ми визначалися з тактикою супроводу вагітності та пологів у кожному випадку залежно від класу кардіоваскулярного і перинатального ризику, конкретної клінічної ситуації та терміну вагітності.

Усі пацієнтки розподілені на такі групи за видом втручання: консервативна, групи втручань на серці та магістральних судинах, кесарського розтину, комбінованої хірургії (кардіохірургічне втручання з кесарським розтином) (діаграма 2).

Iз 53 вагітних і породілей (50 вагітних і 3 породіллі), прооперованих на базі клініки НICCX імені М. М. Амосова, у 14 було проведено кесарський розтин, у 35 пацієнток - кардіохірургічні втручання, у 4 - кардіохірургічні втручання та кесарські розтини.

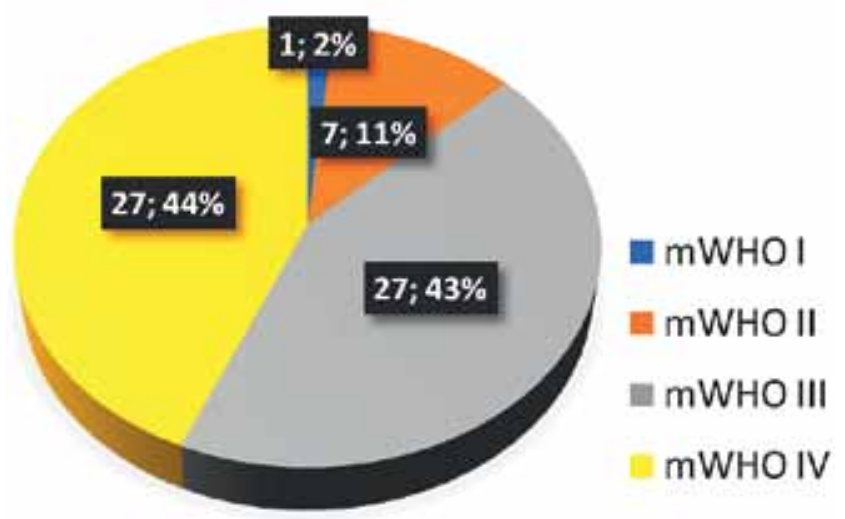

Діаграма 1. Розподіл вагітних за модифікованою шкалою кардіоваскулярного ризику ВООЗ 


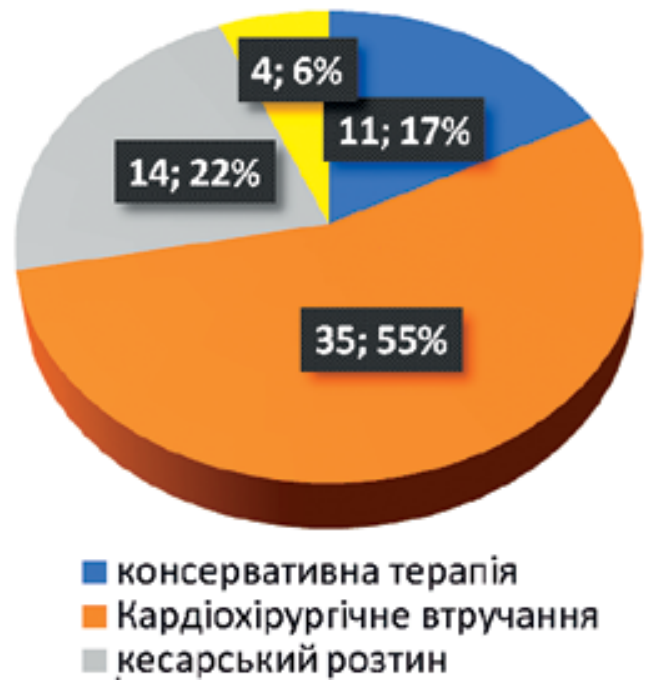

Діаграма 2. Розподіл GUCH-вагітних (породілей) залежно від обраної тактики лікування і супроводу вагітності та пологів
У 53 жінок загалом було проведено 42 втручання на серці та судинах, 18 кесарських розтинів. Серед операцій на серці та судинах були ендоваскулярні втручання $(n=22)$, операції зі штучним кровообігом $(n=19)$, одне «закрите» втручання на стегновій артерії. У плановому порядку проведено 23 операції, в екстреному та невідкладному - 19 втручань на серці та судинах.

У трьох породілей виконано 1 операцію зі штучним кровообігом, 1 гібридне втручання (ендоваскулярне + зі штучним кровообігом), 1 ендоваскулярне втручання та «закриту» операцію на стегновій артерії, причому дві з трьох жінок оперовані в екстреному порядку.

Відповідно, у вагітних (n=50) виконано 17 операцій зі штучним кровообігом і 20 ендоваскулярних операцій.

Типи кардіохірургічних втручань зі штучним кровообігом та основну характеристику пацієнток наведено в табл. 4.

Рішення про проведення планової кардіохірургічної операції приймалися на консиліумі всіма членами мультидисциплінарної команди з урахуванням наяв-

\section{Таблиця 4}

Кардіохірургічні втручання зі штучним кровообігом у GUCH-вагітних (породілей)

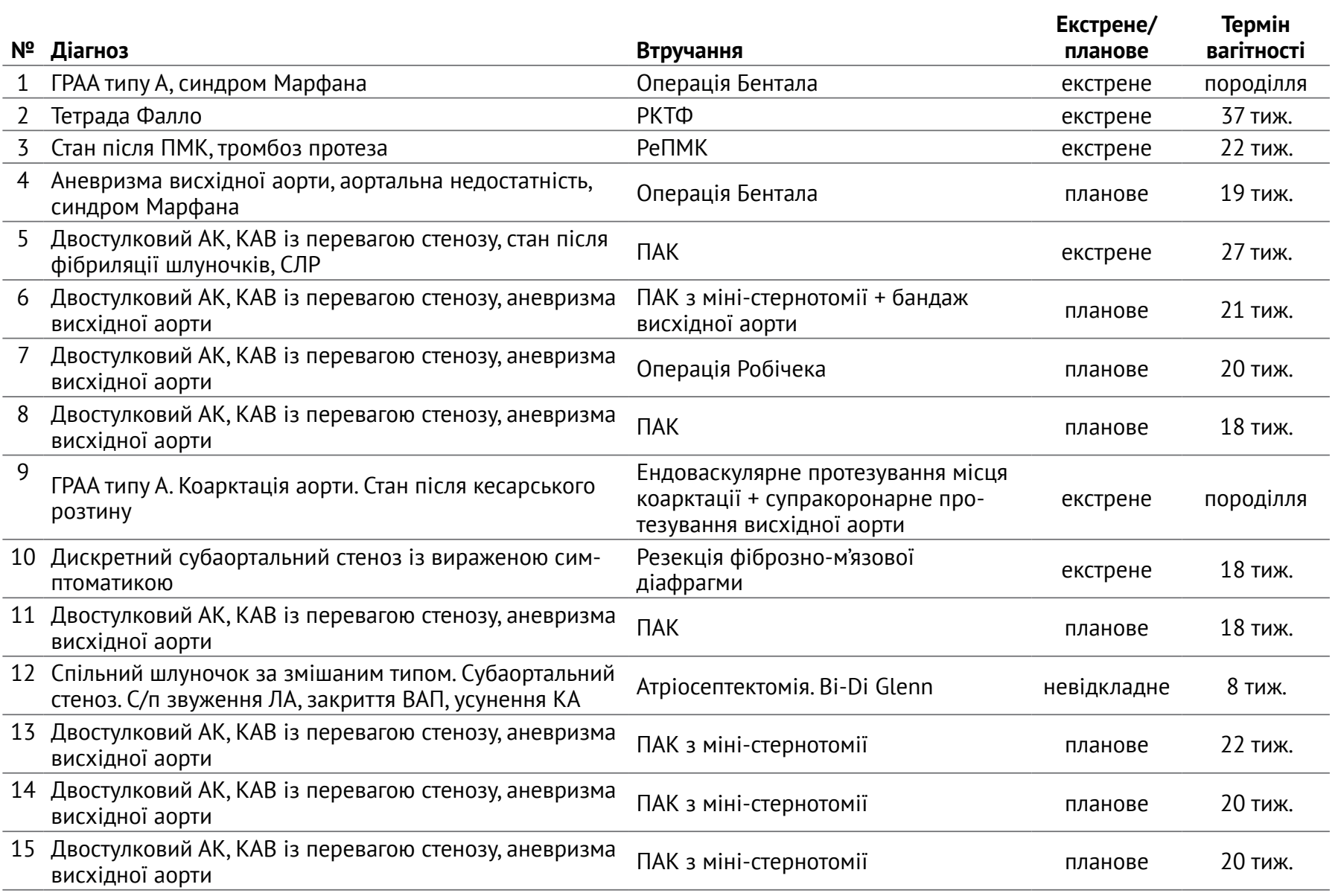




\section{Продовження табл. 4}

\begin{tabular}{|c|c|c|c|c|}
\hline 16 & $\begin{array}{l}\text { Вроджена патологія МК. С/п пластики МК. Виражена } \\
\text { мітральна недостатність }\end{array}$ & Ре-пластика МК + пластика ТК & планове & 21 тиж. \\
\hline 17 & $\begin{array}{l}\text { Двостулковий АК, КАВ із перевагою стенозу, аневризма } \\
\text { висхідної аорти }\end{array}$ & ПАК з міні-стернотомії & планове & 19 тиж. \\
\hline 18 & $\begin{array}{l}\text { Двостулковий АК, КАВ із перевагою стенозу, аневризма } \\
\text { висхідної аорти }\end{array}$ & $\begin{array}{l}\text { ПАК з міні-стернотомії + імплантація } \\
\text { ШВРС }\end{array}$ & планове & 20 тиж. \\
\hline 1 & $\begin{array}{l}\text { Двостулковий АК, КАВ із перевагою стенозу, аневризма } \\
\text { висхідної аорти }\end{array}$ & $\begin{array}{l}\text { ПАК з міні-стернотомії + бандаж } \\
\text { висхідної аорти }\end{array}$ & планове & тиж. \\
\hline
\end{tabular}

* АК - аортальний клапан, ГРАА - гостра розшаровуюча аневризма аорти, КАВ - комбінована аортальна вада, ПАК - протезування аортального клапана, РКТФ - радикальна корекція тетради Фалло, РеПМК - репротезування мітрального клапана, СЛР - серцеволегенева реанімація

них кардіоваскулярних і антенатальних ризиків подальшого виношування та пологів за умови існування некоригованої вади серця та клінічного стану пацієнтки, а також стану плода. 3 огляду на величезний досвід фахівців НІССХ імені М. М. Амосова у проведенні кардіохірургічних втручань і післяопераційному веденні пацієнтів, високопрофесійну підтримку колег акушерів-гінекологів, з одного боку, та існуючі значні ризики дострокового народження для дитини в терміні 25-26 тижнів - з іншого, визначалася така тактика ведення вагітної високого кардіоваскулярного ризику: (1) спостереження та консервативна терапія в першому триместрі - (2) планова кардіохірургія в терміні 18-24 тижні вагітності - (3) пролонгація вагітності до 36-38 тижнів із подальшим розродженням і супроводом $з$ боку мультидисциплінарного колективу. Усі планові кардіохірургічні операції проводилися в умовах нормотермічної (помірно гіпотермічної) перфузії з особливостями у складі перфузату, підвищеними параметрами об'ємної швидкості перфузії, артеріального тиску тощо. На всіх етапах штучного кровообігу проводився моніторинг життєдіяльності плода за оригінальною методикою [12].

Особлива увага з боку мультидисциплінарної команди приділялася вагітним, що мали невідкладний стан і оперувалися в екстреному і невідкладному порядку, незважаючи на термін вагітності та стан плода. Таких пацієнток було 19, їм було проведено 23 втручання (діаграма 3).

Ендоваскулярні втручання - це здебільшого електрофізіологічні процедури імплантації ШВРС $(\mathrm{n}=6)$ та невідкладної радіочастотної абляції $(\mathrm{n}=2)$, а також дилатація критичного стенозу легеневої артерії $(\mathrm{n}=1)$ та рентген-ендоваскулярна дилатація місця коарктації аорти 3 імплантацією ендографта $(\mathrm{n}=3)$. Ендоваскулярні втручання виконувалися в термінах 15-33 тижні вагітності, а також в однієї породіллі.

У групі екстрених і невідкладних втручань було проведено одну гібридну операцію в породіллі з ГРАА типу А, що розвинулася на 3-тю добу після кесарського

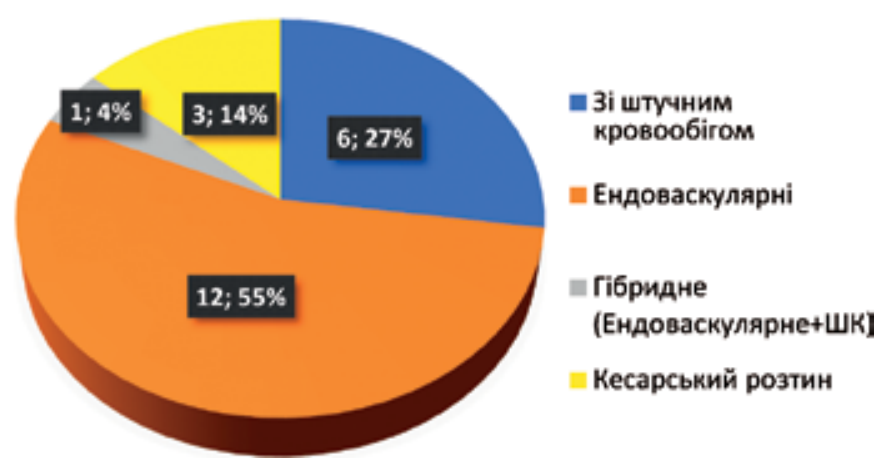

Діаграма 3. Екстрені та невідкладні втручання у вагітних (породілей)

розтину в пацієнтки з помірною коарктацією аорти на тлі проведення трьохкомпонентної антигіпертензивної терапії.

Серед операцій зі штучним кровообігом, виконаних в екстреному та невідкладному порядку, були такі:

- репротезування мітрального клапана на фоні гострого тромбозу протеза в терміні 22 тижні вагітності;

- операція Бентала в породіллі з ГРАА типу А на фоні аортопатії та синдрому Марфана в терміні 40 тижнів вагітності після виконання екстреного кесарського розтину;

- екстрене протезування аортального клапана у вагітної з критичним уродженим стенозом АК, фібриляцією шлуночків і проведенням серцево-легеневої реанімації в терміні 27 тижнів;

- екстрене проведення радикальної корекції тетради Фалло на фоні виконання кесарського розтину, спазму вихідного тракту правого шлуночка, зупинки серця та серцево-легеневої реанімації;

- операція Robicsek (ПАК + екзопротезування висхідної аорти) у вагітної з вродженим критичним стенозом аортального клапана (піковий градієнт 121 мм рт. ст.) та постстенотичною аневризмою ви- 
східної аорти (52 мм) на фоні вираженої симптоматики та серцевої недостатності в терміні 20 тижнів вагітності;

- резекція фіброзно-м'язової субаортальної діафрагми на фоні симптоматичного субаортального стенозу (піковий градієнт на ВТ ЛШ 115 мм рт. ст.) у вагітної в терміні 18 тижнів.

Результати. Безпосередні материнські та антенатальні, а також перинатальні результати значною мірою залежали від вихідного клінічного стану вагітної (породіллі), виду втручання та наявності в неї невідкладного стану (табл. 5).

Материнська та обидві фетальні втрати спостерігалися в групі вагітних (породілей), що підлягали екстреним втручанням зі штучним кровообігом, і причини таких наслідків цілком зрозумілі.

Більше ні материнських втрат, ні фетальних втрат не було. В усіх інших прооперованих жінок $(n=47)$ вагітність закінчилася або строковими пологами, або кесарським розтином на базі Інституту ПАГ або НІCCX

\section{Таблиця 5}

Результати мультидисциплінарного супроводу GUCHвагітних (породілей) залежно від типу і терміновості кардіохірургічного втручання

\begin{tabular}{|c|c|c|c|c|}
\hline $\begin{array}{l}\text { Тип } \\
\text { втручання }\end{array}$ & $\begin{array}{l}\text { Кіль- } \\
\text { кість }\end{array}$ & $\begin{array}{c}\text { Рання ма- } \\
\text { теринська } \\
\text { леталь- } \\
\text { ність }\end{array}$ & $\begin{array}{c}\text { Пізня ма- } \\
\text { теринська } \\
\text { леталь- } \\
\text { ність }\end{array}$ & $\begin{array}{c}\text { Фетальні } \\
\text { втрати }\end{array}$ \\
\hline $\begin{array}{l}\text { Планові без } \\
\text { штучного } \\
\text { кровообігу } \\
\text { («закриті» + } \\
\text { ендоваскулярні) }\end{array}$ & 11 & - & - & - \\
\hline
\end{tabular}

\section{Екстрені без} штучного кровообігу («закриті»+ ендоваскулярні)

Планові

зі штучним кровообігом

\begin{tabular}{|c|c|c|c|c|}
\hline $\begin{array}{l}\text { Екстрені } \\
\text { зі штучним } \\
\text { кровообігом }\end{array}$ & 7 & $1^{*}$ & - & $2^{* *}$ \\
\hline Разом & 42 & 1 & 0 & 2 \\
\hline
\end{tabular}

* Вагітна, 40 тижнів. Гостра розшаровуюча аневризма аорти, синдром Марфана. Кесарів розтин + операція Бентала. Exitus на 8-му добу перед випискою зі стаціонару

** Вагітна, 26 тижнів. Критичний стеноз аортального клапана, піковий градієнт на аортальному клапані 120 мм Нg, фібриляція шлуночків, реанімаційні заходи, екстрене протезування аортального клапана. Антенатальна загибель плода на 3-тю добу після операції

** Вагітна, 22 тижні. Тромбоз протеза МК. Екстрене реПМК. Антенатальна загибель плода на 3-му тижні після операції імені М. М. Амосова без ускладнень, із високими функціональними показниками в новонароджених за шкалою Апгар.

\section{Висновки}

1. Сучасний рівень надання міжсекторальної спеціалізованої допомоги GUCH-вагітним 3 «особливими потребами» значно знижує ризик смертності та інвалідизації матері та дитини.

2. Першою лінією захисту GUCH-жінки фертильного віку є первинна профілактика великих кардіальних подій, а саме: преконцепційне консультування на базі профільних експертних центрів та ії предгравідарна підготовка до вагітності, в тому числі з проведенням кардіохірургічних втручань із ії подальшим мультидисциплінарним супроводом на всіх етапах вагітності, пологів, післяпологового періоду.

3. Оптимальний супровід вагітних із вродженою кардіальною патологією потребує мультидисциплінарної взаємодії фахівців експертних центрів.

4. Вагітні, які належать до III-IV класу ризику за модифікованою шкалою ВООЗ, мають бути направлені до інститутів системи НАМН України (Інститут ПАГ та НICCX імені М. М. Амосова) з метою надання експертної кардіологічної, кардіохірургічної, акушерсько-гінекологічної та перинатальної допомоги.

5. У разі виникнення загрози для життя вагітної з кардіальною патологією високого ризику проведення ургентного кардіохірургічного втручання дає можливість зберегти життя матері, хоча підвищує антенатальні ризики для плода.

\section{Література}

1. Банкл Г. Врождённые пороки сердца и крупных сосудов. Москва: Медицина; 1980.

2. Hoffman JI, Kaplan S. The incidence of congenital heart disease. J Am Coll Cardiol. 2002;39(12):1890-900.

3. Maruszewski B, Lacour-Gayet F, Elliott MJ, Gaynor JW, Jacobs JP, Jacobs ML, et al. Congenital heart surgery nomenclature and database project: update and proposed data harvest. Eur J Cardiothorac Surg. 2002 Jan;21(1):47-9.

4. Warnes CA, Liberthson R, Danielson GK, Dore A, Harris L, Hoffman JI, et al. Task Force 1: The Changing Profile of Congenital Heart Disease in Adult Life. J Am Coll Cardiol. 2001 Apr;37(5):1170-5. https://doi.org/10.1016/ S0735-1097(01)01272-4

5. YuC, Moore BM, Kotchetkova I, Cordina RL, CelermajerDS. Causes of death in a contemporary adult congenital heart disease cohort. Heart. 2018 Oct;104(20):1678-82. https:// doi.org/10.1136/heartjnl-2017-312777

6. Razzaghi H, Oster M, Reefhuis J. Long-Term Outcomes in Children with Congenital Heart Disease: National Health Interview Survey. J Pediatr. 2015 Jan;166(1):119-24. https://doi.org/10.1016/j.jpeds.2014.09.006

7. van Rijen EH, Utens EM, Roos-Hesselink JW, Meijboom FJ, van Domburg RT, Roelandt JR, et al. Psychosocial functioning of the adult with congenital heart disease: a 20-33 years follow-up. Eur Heart J. 2003 Apr;24(7):673-83. 
8. Baumgartner H, Bonhoeffer P, De Groot NM, de Haan F, Deanfield JE, Galie N, et al. ESC Guidelines for the management of grown-up congenital heart disease (new version 2010). Eur Heart J. 2010 Dec;31(23):2915-57. https://doi.org/10.1093/eurheartj/ehq249

9. Regitz-Zagrosek V, Roos-Hesselink JW, Bauersachs J, Blomström-Lundqvist C, Cifková R, De Bonis $\mathrm{M}$, et al. 2018 ESC Guidelines for the management of cardiovascular diseases during pregnancy. Eur Heart J. 2018 Sep;39(34):3165-3241. https://doi.org/10.1093/ eurheartj/ehy340

10. European Society of Gynecology (ESG); Association for European Paediatric Cardiology (AEPC); German Society for Gender Medicine (DGesGM), Regitz-Zagrosek V, Blomstrom Lundqvist C, Borghi C, et al. ESC Guidelines on the management of cardiovascular diseases during pregnancy. Eur Heart J. 2011 Dec;32(24):3147-97. https:// doi.org/10.1093/eurheartj/ehr218

11. Greutmann M, Pieper PG. Pregnancy in women with congenital heart disease. Eur Heart J. 2015;36(37):2491-9. https://doi.org/10.1093/eurheartj/ehv288

12. Лазоришинець ВВ, Сіромаха СО, Давидова ЮВ, Огородник AB, Лук'янова IC, Береговий ОА та ін. Спосіб моніторування стану плоду під час операції на серці матері зі штучним кровообігом. Патент України UA № 129560. 2018 листопад 12.

\title{
Multidisciplinary Support for Pregnant and Parturient with Congenital Heart Disease
}

\author{
Siromakha S. O. ${ }^{1}$, Davydova Y. V. ${ }^{1,2}$, Limanska A. Yu. ${ }^{2}$, Lazoryshynetz V. V. ${ }^{1}$ \\ ${ }^{1}$ National M. M. Amosov Institute of Cardiovascular Surgery National Academy of Medical Sciences of Ukraine (Kyiv) \\ ${ }^{2}$ Institute of Pediatrics, Obstetrics and Gynecology National Academy of Medical Sciences of Ukraine (Kyiv)
}

Adults with corrected or uncorrected congenital heart defects form a separate cohort of patients - GUCH (grown-up with congenital heart). GUCH patients usually have a certain degree of heart failure, arrhythmias, an increased risk of infective endocarditis; some of them require additional heart surgery, with an increased risk of developing sudden cardiac death syndrome. Experts from the European Society of Cardiologists are considering questions and medical support for pregnancy, childbirth and postpartum period in women from a GUCH cohort. In accordance with the ESC recommendations, a multidisciplinary team consisting of specialists from M. Amosov National Institute for Cardiovascular Surgery and the Institute of Paediatrics, Obstetrics and Gynaecology, NAMS of Ukraine, was created in Ukraine in 2013.

Objectives. Reducing maternal and infant mortality and disability, as well as providing optimal management and delivery strategy for pregnant women with congenital cardiac pathology.

Materials and methods. Counselling assistance was provided to 2815 pregnant women with cardiac pathology, 116 women underwent inpatient treatment since 2013. The group of GUCH patients consisted of 64 women, 61 of them were pregnant, 3 were parturient. 52 patients had structural CHD, 12 women suffered from congenital anomalies of the cardiac conduction system. There were patients with a corrected CHD and satisfactory result $(n=4)$, with CHD after palliation or significant residual components of the defect $(n=13)$, and GUCH pregnant with uncorrected CHD $(n=35)$. Some inpatient women received non-surgical treatment $(n=11,17 \%)$. In 53 women (50 pregnant and 3 parturient), who underwent any type of surgery, 42 cardiac and vascular interventions, 18 caesarean sections were performed. Cardiac surgeries included endovascular interventions $(n=22)$, operations with CPB $(n=19)$, one closed intervention on the femoral artery. There were 23 elective operations, and 19 urgent or emergency cases.

Results. One maternal and two foetal losses were observed in a group of pregnant women (parturient) who underwent emergency intervention with CPB. There was no more maternal loss or foetal loss in all other cases $(n=47)$, pregnancies ended either on a term delivery or on a Caesarean section without complications with high functional indicators in newborns by the Apgar scale. The current level of cross-sectoral specialized care for GUCH -pregnant with special needs greatly reduces the risk of mortality and disability in the mother and child.

Conclusions. The first line of defence of GUCH-women of childbearing age involves primary prevention of major cardiac events, namely preconceptional counselling at specialized expert centres, and their preconceptional preparation, multidisciplinary support of such women throughout pregnancy, delivery and postpartum period.

Key words: pregnancy, GUCH, multidisciplinary care. 